Ethos: Jurnal Penelitian dan Pengabdian Masyarakat, Vol 10 No.1, Januari 2022: 114-123

\title{
Metode Fast Untuk Pengenalan Segera Stroke Bagi Warga Muhammadiyah
}

\author{
${ }^{1}$ Sodikin Sodikin, ${ }^{2}$ Assiandi Asiandi, ${ }^{3}$ Sarwito Rachmad Barmawi
}

\author{
${ }^{1}$ Program Studi Keperawatan DIII, Fakultas Ilmu Kesehatan, Universitas Muhammadiyah Purwokerto, \\ ${ }^{2,3}$ Program Studi Ilmu Keperawatan S1, Fakultas Ilmu Kesehatan, \\ Universitas Muhammadiyah Purwokerto \\ E-mail: ${ }^{1}$ sodikin@ump.ac.id; ${ }^{2}$ asiandi@ump.ac.id; ${ }^{3}$ witoito21@gmail.com
}

\begin{abstract}
The World Health Organization (WHO) reported that 15 million people worldwide suffered from stroke per year, of which 5 million dies and 5 million living with permanent disability and becoming a burden to families and communities. Hence, an effective strategy is needed in recognizing the signs and symptoms of stroke, one of which is the "FAST" (Face, Arm, Speech, Time) method. This activity aims to increase the knowledge of Muhammadiyah Branch Management (MBM) members of Rawa Pakis Gumiwang Village on the early detection of stroke with the "FAST" method. This training was applied health education to 30 participants $(n=30)$. Statistical analysis was employed paired t-test and Wilcoxon's test. Knowledge about stroke was significantly different between before and after IbM of stroke detection using the FAST method, $t(d f)=-8.345$ (29), $p<0.001, r=0.84$ and similarly on knowledge about FAST, $T=15, p<0.001, r=-0.71$. The IbM stroke detection program with the FAST method increased participants' knowledge about stroke and the FAST method, both with greater effect. Strengthening through similar training using various methods that are more creative and innovative needs to be done to prevent premature death and life with disabilities due to stroke.
\end{abstract}

Keywords: early detection, stroke, FAST

\begin{abstract}
Abstrak. World Health Organization (WHO) melansir bahwa 15 juta orang di seluruh dunia mengalami stroke per tahunnya; 5 juta meninggal; dan 5 juta dengan hendaya tetap sehingga menjadi beban bagi keluarga dan komunitas. Oleh karena itu, diperlukan strategi yang efektif dalam pengenalan tanda dan gejala stroke, salah satunya dengan metode "FAST"(Face, Arm, Speech, Time). Jadi, tujuan kegiatan ini adalah untuk meningkatkan pengetahuan pada anggota Pengurus Ranting Muhammadiyah (PRM) Rawa Pakis Desa Gumiwang tentang deteksi dini pada penderita stroke dengan metode "FAST". Pelatihan ini menggunakan metode penyuluhan kesehatan terhadap 30 peserta $(n=30)$ yang tergabung dalam PRM Rawa Pakis Desa Gumiwang. Hasil pelatihan ini dianalisis menggunakan analisis statistik uji t tes berpasangan dan uji Wilcoxon. Ada perbedaan bermakna pada pengetahuan tentang stroke sebelum dan sesudah program Ipteks bagi masyarakat (IbM) deteksi stroke dengan metode FAST, $t(d f)=-8,345$ (29), $p<0,001, r=0,84$ dan pada pengetahuan tentang FAST, $T=15$, $p<0,001, r=-0,71$. Program IbM deteksi stroke dengan metode FAST meningkatkan pengetahuan peserta tentang stroke dan tentang metode FAST. Keduanya berdampak efek yang besar. Penguatan melalui pelatihan serupa menggunakan metode beragam yang lebih kreatif dan inovatif. Oleh karenanya, hal ini perlu dilakukan untuk mencegah kematian prematur dan kehidupan dengan disabilitas akibat stroke.
\end{abstract}

Kata Kunci: deteksi dini, stroke, FAST

\section{Pendahuluan}

Peningkatan Penyakit Tidak Menular (PTM) dapat berdampak terhadap peningkatan beban warga dan pemerintah sebab penanggulangannya memerlukan waktu yang lama dan anggaran serta teknologi berbiaya tinggi. Kasus PTM memang tidak ditularkan, tetapi mematikan dan menyebabkan klien tidakproduktifataumengalamipenurunan produktivitas. PTM dapat dicegah melalui deteksi dini. Pengendalian faktor risiko PTM di masyarakat memerlukan 
upaya dan pemahaman yang sama terhadap pembagian peran dan dukungan manajemen program pengendalian PTM, dalam hal ini termasuk pengendalian penyakit stroke (Kemenkes, 2019).

Menurut laporan WHO (2021a), stroke dialami 15 juta orang setiap tahun, sepertiga dari jumlah tersebut meninggal dunia dan sepertigannya lagi mengalami kecacatan menetap sehingga menjadi beban bagi keluarga dan komunitas. Beban stroke tersebut terus menerus meningkat dari 38 juta DALY (Disabilty-Adjusted Life Year) pada tahun 1990 menjadi 61 juta DALY pada tahun 2020. Disabilty-Adjusted Life Year adalah jumlah tahun kehilangan hidup akibat mortalitas prematur dan tahun kehidupan dengan disabilitas (WHO, 2021b). Menurut Virani et al. (2020), mengutip laporan Beban Global Penyakit 2016, rata-rata risiko stroke global dari waktu ke waktu meningkat dari $22,8 \%$ pada tahun 1990 menjadi $24,9 \%$ pada tahun 2016. Satu penelitian di Indonesia menyebutkan bahwa prevalensi stroke keseluruhan di Kabupaten Sleman adalah 1,4\% (0,50\% pria dan 0,90\% wanita). Prevalensi meningkat dengan tambahan puluhan tahun ( $\mathrm{p}<0,001)$. Pada model multivariabel, bertambahnya usia, riwayat hipertensi yang dilaporkan sendiri $(\mathrm{OR}=8,37,95 \% \mathrm{CI}: 4,76-$ 14,69), dan riwayat diabetes mellitus $(\mathrm{OR}=2,87$, CI: 9,54-5,35) secara signifikan berhubungan dengan stroke (Setyopranoto et al., 2019).

Stroke adalah gangguan peredaran darah otak yang dapat menyebabkan kelumpuhan pada ekstremitas, gangguan bicara, dan penurunan kesadaran. Stroke adalah penyakit tidak menular penyebab mortalitas tertinggi dan menyebabkan kecacatan tertinggi di Indonesia (Khariri \& Saraswati, 2021).

Usaha-usaha preventif dan penanggulangan stroke di Indonesia memerlukan pengelolaan yang baik dengan melibatkan berbagai pihak, termasuk masyarakat kampus. Oleh karena itu, program kegiatan ipteks bagi masyarakat ini dilakukan dalam rangka untuk meningkatkan pendeteksian stroke secara dini pada masyarakat, khususnya Pengurus Ranting Muhammadiyah (PRM) Rawa Pakis Desa Gumiwang. Pemilihan PRM sebagai sasaran merupakan bagian dari program kerja khusus Lembaga Penelitian dan Pengabdian kepada Masyarakat (LPPM) Universitas Muhammadiyah Purwokerto untuk memperkuat ketahanan cabang dan ranting Muhammadiyah. Upaya pencegahan stroke sedini mungkin ini adalah gerakan masyarakat hidup sehat (Germas) untuk peningkatan pencegahan dan deteksi dini penyakit (Kemenkes, 2020). Hasil penelitian Widjaja et al. (2020) di Surabaya pada 215 responden menunjukkan bahwa sejumlah $76,7 \%$ pengetahuan terhadap stroke masih rendah. Selain itu, stroke bagi penderita adalah beban kehidupan yang mengganggu (Norris, Allotey, \& Barrett, 2012). Oleh karena itu, diperlukan upaya-upaya untuk mendeteksi stroke sedini mungkin untuk mencegah terjadi stroke yang merupakan beban bagi klien, keluarga, dan komunitas. Kegiatan deteksi dini stroke ini adalah upaya promotif, preventif, dan pengurangan risiko PTM dengan pemberdayaan masyarakat (Kemenkes, 2019). Salah satu upaya tersebut dapat dilakukan dengan pelatihan pengenalan tanda dan gejala stroke bagi masyarakat menggunakan metode FAST.

"FAST" merupakan akronim dari Facial movement, Arm movement, Speech, dan Time to call yang dapat digunakan untuk mengetahui dan mendeteksiterjadinya stroke (Kleindorfer et al., 2007; Kothari, Pancioli, Liu, Brott, \& Broderick, 1999). Tanda dan gejala tersebut dapat digunakan sebagai panduan untuk segera melakukan pertolongan pertama bagi klien stroke atau mendapatkan penanganan medis sesegera mungkin. 


\section{Metode Penelitian}

Kegiatan pelatihan pengenalan dini stroke dengan menggunakan metode FAST ini dilakukan di PRM Rawa Pakis Purbalingga terhadap 30 peserta di Desa Gumiwang. Kegiatan pelatihan merupakan program Ipteks bagi masyarakat (IbM) yang dibiayai oleh LPPM Universitas Muhammadiyah Purwokerto. Kegiatan pelatihan dilakukan sebulan sekali dalam rentang waktu tiga bulan (Januari-Maret 2020). Indikator pencapaian program adalah peningkatan skor pengetahuan terkait deteksi dini stroke menggunakan metode FAST, yakni (kemampuan menyebutkan adanya facial movement [perubahan bentuk wajah], arm movement [tidak dapat menggerakkan tangan], speech [adanya gangguan bicara], dan time to call [segera menelepon ke rumah sakit terdekat untuk meminta pertolongan]). Evaluasi pencapaian pelatihan dilakukan seminggu sebelum dan seminggu sesudah pelatihan dengan memberikan lembar kuesioner berisi pertanyaan terkait dengan FAST tersebut.

\section{Hasil dan Pembahasan}

Hasil kegiatan program IbM tentang pengenalan stroke dengan metode FAST disajikan pada tabel dan gambar (lihat tabel 1-6 dan gambar 1-4). Uji normalitas data menunjukkan data berdistribusi normal untuk variabel pengetahuann tentang stroke sebelum dan sesudah program IbM, $p=0,167$, sehingga analisis statistik menggunakan paired $t$ test. Normalitas data terpenuhi untuk variabel pengetahuan tentang metode FAST sebelum dan sesudah program IbM, $p<0,001$. Dengan begitu, analisis statistika menggunakan uji Wilcoxon.

Hasil pada tabel 1 dan ilustrasi pada gambar 1-4 menunjukkan bahwa usia tubuh (body age) peserta lebih rendah dari usia kronologisnya $(49,40 \pm 10,93$ tahun). Usia tubuh diukur menggunakan monitor komposisi tubuh (KaradaScan Body Scan Monitor Model HBF-375, Omron Healthcare Co., Ltd., Japan). Usia tubuh dihitung berdasarkan berat badan dan persentase lemak tubuh untuk menentukan apakah usia tubuh di atas atau di bawah usia sebenarnya. Kebanyakan TDS dan TDD sebagai peserta berada dalam kisaran normal.

Tabel 1. Karakteristik peserta program Ipteks bagi Masyarakat (IbM) deteksi dini stroke dengan metode FAST

\begin{tabular}{lccc}
\hline Karakteristik & $\boldsymbol{M}(\boldsymbol{S D})$ & Minimal & Maksimal \\
\hline Usia (tahun) & $\begin{array}{c}52,77 \\
(10,19)\end{array}$ & 29 & 72 \\
\hline $\begin{array}{l}\text { Usia tubuh } \\
\text { (tahun) }\end{array}$ & $\begin{array}{c}49,40 \\
(10,93)\end{array}$ & 26 & 70 \\
\hline TDS (mm Hg) & $\begin{array}{c}127,67 \\
(14,06)\end{array}$ & 100 & 160 \\
\hline TDD (mm Hg) & $\begin{array}{l}84,33 \\
(8,54)\end{array}$ & 70 & 110 \\
\hline GDS (mg/dL) & $\begin{array}{l}128,60 \\
(34,34)\end{array}$ & 57 & 274 \\
\hline
\end{tabular}

Keterangan: TDS, tekanan darah sistolik; TDD, tekanan darah diastolik; GDS, gula darah sewaktu.

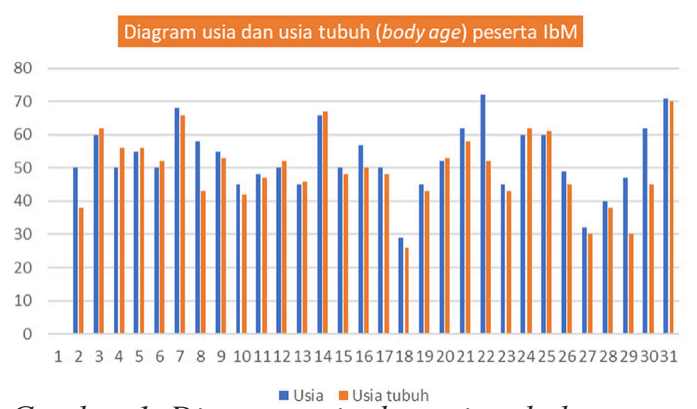

Gambar 1. Diagram usia dan usia tubuh peserta IbM pengenalan segera stroke dengan metode FAST

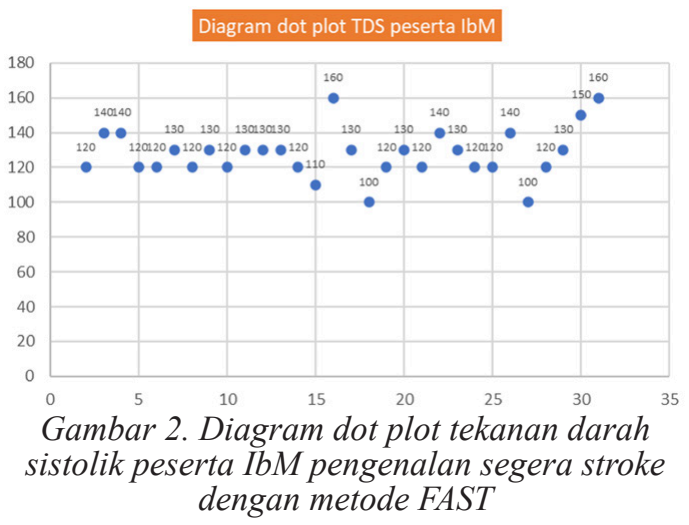




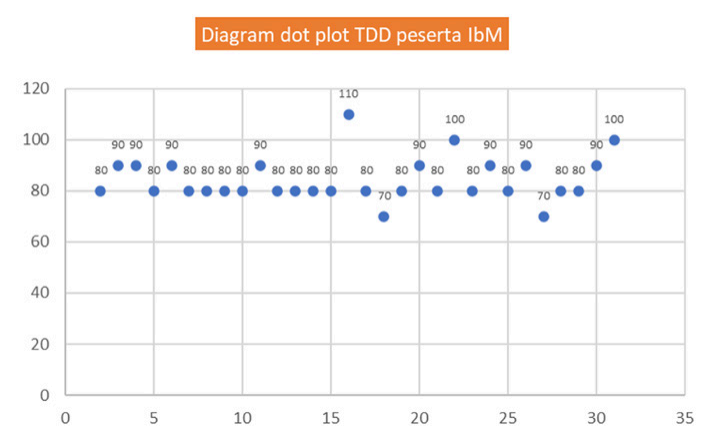

Gambar 3. Diagram dot plot tekanan darah diastolik peserta IbM pengenalan segera stroke dengan metode FAST

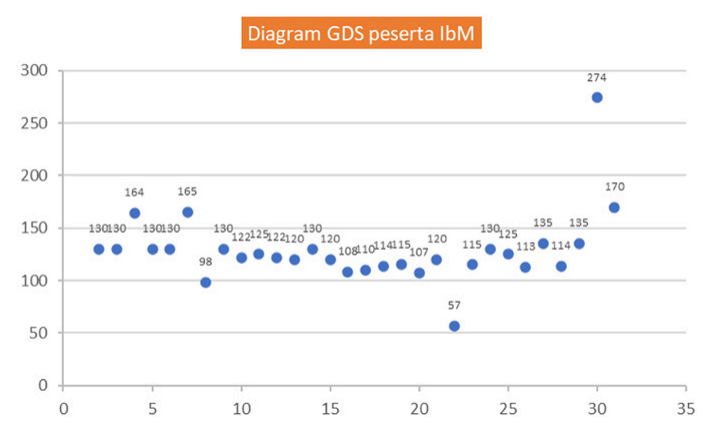

Gambar 4. Diagram dot plot gula darah sewaktu peserta IbM pengenalan segera stroke dengan metode FAST

Kebanyakan peserta dengan GDS juga dalam kisaran normal (normalnya 70-130 mg/dL). Hasil pengukuran tersebut dilakukan berdasarkan data pengukuran yang dikumpulkan oleh anggota tim pelatihan.

Berdasarkan hasil pada Tabel 3 dan Tabel 4, pengetahuan peserta tentang stroke mengalami peningkatan antara sebelum dan sesudah program IbM. Pelatihan deteksi dini stroke dengan metode FAST dapat meningkatkan nilai tengah/median $(M d n)$ pengetahuan dari 80 menjadi 90 dan terjadi penurunan rentang nilai (range) dari sebelum range 70 (100-70) menjadi range 40 (100-60). Pengetahuan peserta tentang metode FAST juga menunjukkan bahwa peningkatan antara sebelum dan sesudah program IbM. Pelatihan pengenalan segera stroke menggunakan metode FAST menaikkan median $(M d n)$ pengetahuan peserta tentang metode FAST dari 87,50 sebelum menjadi 100 sesudah pelatihan dan juga
Tabel 2. Data peringkat (ranking) pengetahuan tentang metode FAST antara sesudah dan sebelum program IbM deteksi dini stroke dengan metode FAST menurut uji Wilcoxon Signed Ranks

\begin{tabular}{lccc}
\hline & $\boldsymbol{N}$ & $\begin{array}{c}\text { Rerata } \\
\text { Peringkat }\end{array}$ & $\begin{array}{c}\text { Jumlah } \\
\text { Peringkat }\end{array}$ \\
\hline Peringkat negatif & $0^{\mathrm{a}}$ & 0,00 & 0,00 \\
\hline Peringkat positif & $15^{\mathrm{b}}$ & 8,00 & 120,00 \\
\hline Ties & $15^{\mathrm{c}}$ & & \\
\hline Total & 30 & & \\
\hline
\end{tabular}

Keterangan: Pengetahuan tentang metode FAST;

${ }^{\text {a }}$ sesudah $<$ sebelum; ${ }^{\text {b }}$ sesudah $>$ sebelum; ${ }^{\mathrm{c}}$ sesudah $=$ sebelum.

Tabel 3. Rerata skor pengetahuan peserta tentang stroke sebelum dan sesudah program IbM $(N=30)$

\begin{tabular}{lcccc}
\hline Pengetahuan & $\boldsymbol{M}(\boldsymbol{S D})$ & $\boldsymbol{M d n}$ & Min. & Maks. \\
\hline Sebelum & $\begin{array}{c}74,57 \\
(15,96)\end{array}$ & 80 & 30 & 100 \\
& $\begin{array}{c}89,67 \\
(10,98)\end{array}$ & 90 & 60 & 100 \\
\hline Sesudah & & & \\
\hline
\end{tabular}

Keterangan: M (SD), mean (standard deviasi); $M d n$, median; Min., skor minimal; Maks., skor maksimal.

Tabel 4. Rerata skor pengetahuan peserta tentang metode FAST sebelum dan sesudah program IbM $(N=30)$

\begin{tabular}{lcccc}
\hline Pengetahuan & $\boldsymbol{M}(\boldsymbol{S D})$ & Mdn & Min. & Maks. \\
\hline Sebelum & $\begin{array}{c}83,33 \\
(20,06)\end{array}$ & 87,50 & 25 & 100 \\
& $\begin{array}{c}95,83 \\
\text { Sesudah }\end{array}$ & 100 & 50 & 100 \\
& $(11,53)$ & & & \\
\hline
\end{tabular}

Keterangan: M (SD), mean (standard deviasi); Mdn, median; Min., skor minimal; Maks., skor maksimal.

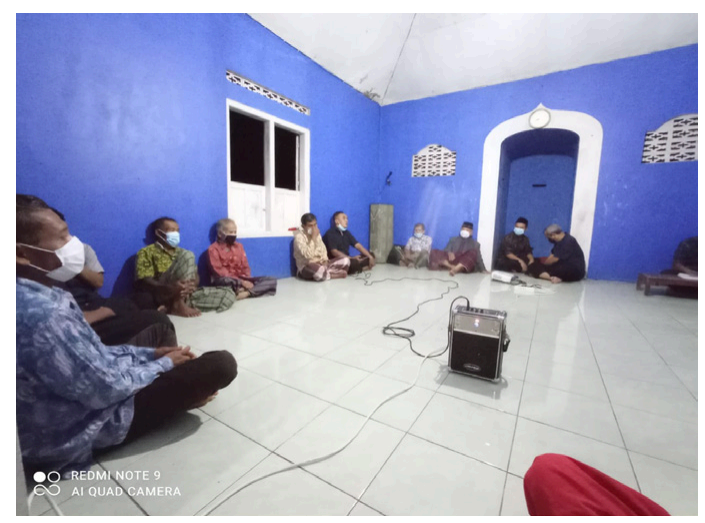

Gambar 4. Pelaksanaan IbM pengenalan segera stroke dengan metode FAST

terjadi penurunan rentang nilai dari range 75 turun menjadi range 50 . 
Tabel 5. Rerata perbedaan pengetahuan peserta IbM tentang stroke sebelum dan sesudah pelatihan pengenalan segera stroke dengan metode FAST

\begin{tabular}{|c|c|c|c|c|c|}
\hline & \multicolumn{2}{|c|}{ Perbedaan } & \multirow{2}{*}{$t(d f)$} & \multirow{2}{*}{$p$} & \multirow{2}{*}{$r$} \\
\hline & $M$ & $S D$ & & & \\
\hline $\begin{array}{l}\text { Pengetahuan } \\
\text { sebelum } \\
\text { dan sesudah } \\
\text { pelatihan }\end{array}$ & $-15,10$ & 9,91 & $\begin{array}{l}-8,345 \\
(29)\end{array}$ & $<0,001$ & 0,84 \\
\hline
\end{tabular}

Tabel 6 . Perbedaan pengetahuan peserta IbM tentang metode FAST sebelum dan sesudah pelatihan pengenalan segera stroke dengan metode FAST

\begin{tabular}{lccc}
\multicolumn{1}{c}{ Pengetahuan } & $\boldsymbol{z}$ & $\boldsymbol{p}$ & $\boldsymbol{r}$ \\
\hline $\begin{array}{l}\text { Sebelum dan } \\
\text { sesudah }\end{array}$ & $-3,873$ & $<0,001$ & $-0,71$ \\
\hline
\end{tabular}

Berdasarkan hasil pada tabel 5 dan 6, pengetahuan tentang stroke sebelum dan sesudah program IbM deteksi stroke dengan metode FAST berbeda secara bermakna, $\mathrm{t}(\mathrm{df})=-8,345$ (29), $\mathrm{p}<0,001, \mathrm{r}=0,84$. Pengetahuan tentang FAST sebelum dan sesudah program IbM deteksi stroke dengan metode FAST berbeda secara bermakna, $\mathrm{T}=15, \mathrm{p}<0,001, \mathrm{r}=-0,71 . \mathrm{T}$ adalah melambangkan uji Wilcoxon dan nilai peringkat positifnya dan $\mathrm{r}$ adalah effect size (pengaruh).

Hasil perhitungan $\mathrm{r}$ menunjukkan bahwa pengetahuan tentang stroke setelah pelatihan adalah 0,84 (menunjukkan efek besar pelatihan deteksi dini stroke dengan metode FAST) (Cohen, 1988). Pada uji Wilcoxon, perhitungan effect size menggunakan rumus (Rosenthal, 1991, hlm. 19). Dampak program IbM deteksi stroke dengan metode FAST meningkatkan pengetahuan peserta tentang stroke dan tentang metode FAST. Keduanya berdampak dengan efek yang besar.

Hasil pelatihan deteksi dini stroke dengan metode FAST pada PRM Muhammadiyah Rawa Pakis, Purbalingga menunjukkan bahwa usia tubuh (body age) peserta lebih rendah daripada usia biologisnya, TDS, TDD, dan GDS berada dalam kisaran normal. Hal ini menggambarkan bahwa warga Muhammadiyah Ranting Rawa Pakis sehat menurut karakteristik data tersebut. Pada pelatihan ini, kami melakukan pengukuran usia tubuh karena usia tubuh sangat penting diketahui untuk meningkatkan kondisi tubuh. Usia tubuh dihitung berdasarkan berat badan dan persentase lemak tubuh yang dihitung menggunakan impedansi bioelektrik dan kemudian dikategorikan di bawah atau di atas rerata usia sebenarnya.

Pelatihan ini dapat meningkatkan nilai median $(M d n)$ pengetahuan dari 80 menjadi 90 dan menurunkan range skor 70 menjadi range 40. Pelatihan ini dapat meningkatkan median $(M d n)$ pengetahuan peserta tentang metode FAST dari 87,50 sebelum pelatihan menjadi 100 sesudah pelatihan dan juga terjadi penurunan rentang nilai dari range 75 turun menjadi range 50. Menurut Rachmawati, Ningsih, dan Andarini (2020), berdasarkan penelitiannya di Jawa Timur, Indonesia; pengetahuan tentang indikasi dini stroke sangat dipengaruhi pengetahuan sebelumnya tentang stroke dan pendidikan. Di Libanon, Khalil dan Lahoud (2020) menemukan pengetahuan $(\mathrm{OR}=2,51, \mathrm{p}<0,001), \quad$ memiliki gangguan irama jantung $(\mathrm{OR}=1,873$, $\mathrm{p}=0,025)$, dan level pendidikan (OR = $2,806, p=0,012)$. Hal itu adalah prediktor untuk menyebutkan lebih banyak gejala dan faktor risiko stroke. Di Arab Saudi, Naguib et al. (2020) menemukan bahwa mayoritas mereka yang memanggil ambulans dalam 3 jam adalah berusia muda (pelajar) dan kebanyakan mampu menyebutkan minimal 5 faktor risiko dan hampir tiga perempat dapat menyebutkan 3 tanda peringatan stroke. Di Nigeria, Komolafe et al. (2015) juga menemukan ada korelasi positif antara tingkat pendidikan dengan kesadaran pada faktor risiko dan tanda peringatan stroke.

Di Indonesia, Alfira (2019) pernah melakukan penyuluhan FAST terhadap perawat dalam melakukan penegenalan 
segera stroke. Berbeda dengan Alfira (2019), pelatihan ini dilakukan untuk mengetahui dampak pelatihan pengenalan segera stroke pada warga Muhammadiyah di ranting Rawa Pakis, Purbalingga. Mengacu pada besaran effect size (Cohen, 1988), pelatihan ini menunjukkan efek yang besar terhadap peningkatan pengetahuan peserta tentang stroke dan tentang metode FAST.

PenggunaanjembatankeledaiFAST pada dasarnya memiliki kelemahan dari segi bahasa. Oleh karena itu, kampanye menggunakan FAST lebih tepat jika diterapkan di negara-negara berbahasa Inggris. Negara China dan Taiwan sudah mengembangkan kampanye pengenalan tanda dan gejala stroke sendiri kepada masyarakat dengan metode Stroke 1-2-0 dan Stroke 112 (Zhao, Eckenhoff, Sun, \& Liu, 2018; Zhao et al., 2020).

Sebuah kampanye edukasi Stroke 1-2-0, artinya adalah 1 mewakili pertama, melihat wajah tidak simetris; 2 mewakili pemeriksaan kedua terhadap kelemahan lengan; 0 (nol) mewakili tidak dapat berbicara jelas. Jadi, hal itu merupakan nomor layanan panggilan gawat darurat 120 (Zhao et al., 2020). Kampanye dilakukan selama 2 tahun di China dengan cakupan media yang masif dan sesi pendidikan berbasis komunitas dengan video dan materi terkait lainnya. Hasil kampanye dievaluasi menggunakan survei yang dilakukan terhadap 3.066 peserta tahun 2016 dan 15.207 peserta pada tahun 2018. Hasil survei menunjukkan bahwa angka penerimaan Stroke 1-2-0 versus FAST adalah 50,2\% versus $19,1 \%$ pada 2016 dan mengalami perubahan yang bermakna menjadi $82,2 \%$ versus $8,0 \%$ pada 2018 (Zhao et al., 2020).

Hasil yang serupa juga ditemukan dari hasil evaluasi penerapan Stroke 112, yakni 1 wajah tidak simetris; 1 kelemahan lengan; 2 bibir yang inkoherens (bicara cadel). Jadi, itu akan menghasilkan nomor 112 yang merupakan nomor panggilan emergensi internasional yang digunakan di lebih dari 70 negara (Zhao et al., 2018). Survei awal terhadap 465 responden menunjukkan bahwa 54,6\% berpikir bahwa Stroke 112 mudah diingat untuk warga Taiwan dibandingkan 41,2\% untuk FAST pada Agustus 2017. Kemudian setelah resmi dilincurkan pada Maret 2018 survei terhadap 610 responden menunjukkan $66,4 \%$ berpikir Stroke 112 mudah diingat, meningkat signifikan dibandingkan survei awal $(\mathrm{p}=$ 0,0001). Di antara 130 neurologis yang menghadiri kuliah pendahuluan Stroke 112, sebanyak 55 orang melengkapi survei daring. Penerimaan terhadap Stroke 122 sangat besar $(74,6 \%)$ dibandingkan dengan FAST (16,4\%) (p $=0,0001)$ (Zhao et al., 2018).

Penelitian acak yang dilakukan Tsai et al. (2021) menunjukkan bahwa hasil yang sangat berbeda dengan kedua penelitian sebelumnya. Penelitian mereka terhadap 202 partisipan pada kelompok FAST dan 193 partisipan kelompok Stroke 112 menunjukkan bahwa tidak adanya perbedaan dalam kemampuan menyebutkan kembali (recall) pada hari ke-5 atau hari ke-30 setelah edukasi. Kemampuan menyebutkan kembali tanda-tanda stroke pada kelompok FAST vs. Stroke 112 masing-masing: face $(87,1 \%$ vs. $76,7 \%)$, arm $(87,1 \%$ vs. $88,1 \%)$, dan speech $(78,7 \%$ vs. $76,7 \%$ ) pada hari ke-5. Kemampuan menyebukan kembali masih sama pada hari ke-30 hanya untuk item arm $(86,1 \%$ vs. $88.6 \%$ ).

Efek pelatihan yang besar pada pelatihan ini perlu mendapatkan upayaupaya penguatan yang berkelanjutan, mengingat kegiatan penyadaran masyarakat tentang stroke dan tentang FAST yang serupa seperti kampanye dan iklan menunjukkan dampak yang berbeda-beda dalam jangka panjang. Kampanye efektif dalam meningkatkan kesadaran masyarakat terhadap tanda dan gejala stroke. Kampanye iklan media masa mampu meningkatkan kemampuan komunitas terpapar menyebutkan $\geq 2$ 
tanda peringatan stroke (Silver, Rubini, Black, \& Hodgson, 2003). Namun, disebutkan bahwa iklan koran dan iklan televisi hanya efektif bagi usia muda dan tidak efektif pada usia $\geq 65$ tahun (Sobotkova, Goldemund, Reif, \& Mikulik, 2014). Menurut Sudirman, Yuliyanti, dan Sari (2018), kampanye mungkin dapat meningkatkan kesadaran masyarakat terhadap tanda stroke, tetapi berdampak terbatas pada perilaku sehingga menurut mereka, hal itu perlu peningkatan kampanye FAST yang disertai penyadaran terhadap faktorfaktor risiko yang dapat dimodifikasi untuk dapat menurunkan insidensi stroke dan meningkatkan kualitas hidup orang banyak.

Penelitian Handayani (2019) di RSUD Tugurejo Semarang dan RS Kanjeng Raden Mas Tumenggung Semarang, Indonesia, menyimpulkan bahwasemuaresponden yang terdiagnosis stroke iskemik $(\mathrm{n}=70)$ berpengetahuan buruk dalam menjawab kuesioner Stroke Knowledge Test. Masing-masing prosentase yang menjawab benar tentang tipe stroke, prevalensi, kecacatan akibat stroke, dan pencegahan adalah 12,8\%, $0 \%$, 35,9\%, dan 11,5\%. Responden yang menjawab benar diabetes, atrial fibrilasi, umur, obesitas, TIA, hipertensi, alkohol, dan merokok sebagai faktor risiko masing-masing adalah $11,5 \%, 0 \%$, $12,8 \%, 12,8 \%, 2,6 \%, 41 \%, 6,4 \%$, dan $3,8 \%$. Responden yang menjawab benar tentang tanda-tanda peringatan TIA dan tanda peringatan stroke masing-masing adalah $0 \%$ dan $11,5 \%$. Responden yang menjawab benar tentang respons memanggil ambulan ketika serangan hanya ada 6,4\%. Menurut Sobotkova et al. (2014), responsivitas terhadap informasi terkait stroke meningkat pada orang yang memiliki faktor risiko stroke (penyakit jantung dan obesitas) dan terjadi penurunan responsivitas pada perokok sebagaimana juga terbukti hanya $3,8 \%$ pasien stroke iskemik di Semarang, Indonesia yang menganggap rokok sebagai faktor risiko (Handayani, 2019). Partisipan penelitian di Beirut, Libanon, mengetahui bahwa rokok adalah faktor risiko stroke sebesar 20,5\% dengan pertanyaan terbuka, lebih tinggi dibandingkan anggapan partisipan di Indonesia (Handayani, 2019; Khalil \& Lahoud, 2020). Menurut Khalil dan Lahoud (2020) diperlukan kampanye sesuai dengan budaya, khususnya bagi lansia di Beirut, Libanon. Menurutnya, kampanye harus berisi tentang peningkatan kesadaran gejala stroke dan aksi yang harus dilakukan ketika dicurigai mengalami stroke.

Pelatihan ini memiliki beberapa keterbatasan. Pelatihan hanya dilakukan terhadap 30 peserta sehingga kesimpulan hasil pelatihan ini tidak dapat digeneralisasi. Metode pelatihan ini mungkin kurang efektif, tetapi mampu menjangkau masyarakat secara langsung. Beberapa metode lain mungkin lebih efektif, tetapi membutuhkan biaya yang lebih besar, misalnya, dengan kampanye media massa (Rasura et al., 2014). Menurut Marx, Nedelmann, Haertle, Dieterich, dan Eicke (2008), program edukasi kemungkinan tidak menimbulkan perubahan pada perilaku pencarian penanganan stroke. Sebagaimana juga disimpulkan Sudirman et al. (2018), bahwa kampanye mungkin kurang berdampak pada perilaku. Oleh karena itu, diperlukan upaya promotif dan preventif terhadap para klien stroke yang dapat mengubah perilaku seperti dengan melakukan olahraga atau kegiatan bersama komunitas orang dengan stroke (ODS).

\section{Kesimpulan dan Saran}

Pelatihan ipteks bagi masyarakat pada warga dan pengurus ranting Muhammadiyah (PRM) Rawa Pakis Desa Gumiwang Purbalingga tentang deteksi dini stroke dengan metode FAST memberikan dampak besar pada peningkatan pengetahuan tentang stroke 
dan peningkatan pengetahuan tentang FAST. Dampak dari pelatihan ini adalah perlu dilakukan upaya penguatan berkelanjutan mengingat upaya-upaya penyadaran dalam bentuk pelatihan dan upaya serupa lainnya seperti kampanye dan iklan biasanya tidak berdampak untuk jangka panjang. Kami merekomendasikan perlunya pembinaan dan penyadaran bagi warga dan PRM Rawa Pakis dan PRM lainnya untuk dapat terus dilakukan pelatihan tentang stroke dan penyakit-penyakit terkait lainnya dalam rangka mencegah peningkatan tahun kehilangan hidup akibat mortalitas premature, tahun kehidupan dengan disabilitas, serta membantu menurunkan prevalensi penyakit tidak menular lainnya.

\section{Ucapan Terima Kasih}

$\begin{array}{clr}\text { Terima } & \text { kasih kami } & \text { sampaikan } \\ \text { kepada } & \text { LPPM } & \text { Universitas }\end{array}$ Muhammadiyah Purwokerto yang telah memberikan hibah sehingga pelatihan dan desiminasi ipteks bagi masyarakat ini dapat terlaksana. Terima kasih juga kami sampaikan kepada PRM Rawa Pakis Desa Gumiwang Purbalingga yang telah berpartisi aktif dalam kegiatan selama pelatihan dilaksanakan.

\section{DAFTAR PUSTAKA}

Alfira, N. (2019). Pengaruh penyuluhan metode FAST terhadap pengetahuan perawat dalam deteksi dini penyakit stroke di RSUD H. A. Sulthan Daeng Radja Kabupaten Bulukumba. Jurnal Ilmiah Kesehatan Diagnosis 14(1), 58-61.

Cohen, J. (1988). The concepts of power analysis. In J. Cohen (Ed.), Statistical Power Analysis for the Behavioral Sciences (2nd ed., pp. 1-17). Hillsdale, NJ: Lawrence Elbaum Associate.

Handayani, F. (2019). Pengetahuan tentang stroke, faktor risiko, tanda peringatan stroke dan respon mencari bantuan pada pasien stroke iskemik di Kota Semarang. Jurnal Ilmu Keperawatan Medikal Bedah, 2(2), 12-21.

Kemenkes. (2019). Strategi Pencegahan dan Pengendalian PTM di Indonesia. Retrieved from http:// www.p2ptm.kemkes.go.id/profilp2ptm/latar-belakang/strategipencegahan-dan-pengendalianptm-di-indonesia

Kemenkes. (2020). Indikator Program Kesehatan Masyarakat dalam RJPMN dan Renstra Kementerian Kesehatan 2020-2024. Jakarta: Kementerian Kesehatan RI.

Khalil, H. M., \& Lahoud, N. (2020). Knowledge of stroke warning signs, risk factors, and response to stroke among Lebanese older adults in Beirut. Journal of Stroke and Cerebrovascular Diseases, 29(5), 104716. doi:10.1016/j. jstrokecerebrovasdis.2020.104716

Khariri, \& Saraswati, R. D. (2021). Transisi epidemiologi stroke sebagai penyebab kematian pada semua kelompok usia di Indonesia. Paper presented at the Seminar Nasional Riset Kedokteran (SENSORIK II).

Kleindorfer, D. O., Miller, R., Moomaw, C. J., Alwell, K., Broderick, J. P., Khoury, J., . . Kissela, B. M. (2007). Designing a message for public education regarding stroke: does FAST capture enough stroke? Stroke, 38(10), 2864-2868. doi:10.1161/strokeaha.107.484329

Komolafe, M. A., Obembe, A. O., Olaogun, M. O., Adebiyi, A. M., Ugalahi, T., Dada, O., . . . Fawale, B. (2015). Awareness of stroke risk factors and warning signs in Nigerian adolescents compared with adults. Journal of Stroke and Cerebrovascular Diseases, 24(3), 687-693. doi:10.1016/j. 
jstrokecerebrovasdis.2014.11.013

Kothari, R. U., Pancioli, A., Liu, T., Brott, T., \& Broderick, J. (1999). Cincinnati Prehospital Stroke Scale: Reproducibility and validity. Annals of Emergency Medicine, 33(4), 373-378.

Marx, J. J., Nedelmann, M., Haertle, B., Dieterich, M., \& Eicke, B. M. (2008). An educational multimedia campaign has differential effects on public stroke knowledge and care-seeking behavior. Journal of Neurology, 255(3), 378-384. doi:10.1007/s00415-008-0673-5

Naguib, R., Fayed, A., AlFadhliah, A. B., AlMansour, N. S., AlDakheel, R. M., \& AlQahtani, R. M. (2020). Awareness about stroke and proper actions to be taken; A room for improvement. Journal of Stroke and Cerebrovascular Diseases, 29(6), 104794. doi:10.1016/j. jstrokecerebrovasdis.2020.104794

Norris, M., Allotey, P., \& Barrett, G. (2012). 'It burdens me': the impact of stroke in central Aceh, Indonesia. Sociology of Health and Illness, 34(6), 826-840. doi:10.1111/ j.1467-9566.2011.01431.x

Rachmawati, D., Ningsih, D. K., \& Andarini, S. (2020). Factors affecting the knowledge about stroke risks and early symptoms in emergency department. MNJ: Malang Neurology Journal, 6(1), 11-19. doi:10.21776/ ub.mnj.2020.006.01.3

Rasura, M., Baldereschi, M., Di Carlo, A., Di Lisi, F., Patella, R., Piccardi, B., . . . Inzitari, D. (2014). Effectiveness of public stroke educational interventions: A review. European Journal of Neurology, 21(1), 1120. doi:10.1111/ene. 12266

Rosenthal, R. (1991). Meta-analytic Procedure for Social Research (2nd ed.). Newbury Park/New Delhi: Sage Publication, Inc.

Setyopranoto, I., Bayuangga, H. F.,
Panggabean, A. S., Alifaningdyah, S., Lazuardi, L., Dewi, F. S. T., \& Malueka, R. G. (2019). Prevalence of Stroke and Associated Risk Factors in Sleman District of Yogyakarta Special Region, Indonesia. Stroke Research and Treatment, 2019, 2642458. doi: $10.1155 / 2019 / 2642458$

Silver, F. L., Rubini, F., Black, D., \& Hodgson, C. S. (2003). Advertising strategies to increase public knowledge of the warning signs of stroke. Stroke, 34(8), 1965-1968. doi:10.1161/01. STR.0000083175.01126.62

Sobotkova, P., Goldemund, D., Reif, M., \& Mikulik, R. (2014). Predictors of noticing stroke educational campaign. Journal of Stroke and Cerebrovascular Diseases, 23(6), 1662-1668. doi:10.1016/j. jstrokecerebrovasdis.2014.01.013

Sudirman, H., Yuliyanti, C., \& Sari, A. I. (2018). Effectiveness of 'FAST' stroke campaign for fast stroke recognition and response: A systematic review. Paper presented at the International Conference on Applied Science and Health

Tsai, Y. T., Li, R., Jao, T., Fang, C. W., Hsiao, Y. J., Tsai, C. H., \& Chang, K. C. (2021). Comparison of FAST and Stroke-112: A randomized study in Taiwan. Journal of the Formosan Medical Association. doi:https://doi.org/10.1016/j. jfma.2021.02.018

Virani, S. S., Alonso, A., Benjamin, E. J., Bittencourt, M. S., Callaway, C. W., Carson, A. P., . . . Stroke Statistics, S. (2020). Heart disease and stroke statistics-2020 update: A report from the American Heart Association. Circulation, 141(9), e139-e596. doi:10.1161/ CIR.0000000000000757

WHO. (2021a). The Atlas of Heart Disease and Stroke. Global burden of stroke. Retrieved from https:// 
www.who.int/cardiovascular diseases/en/cvd atlas 15 burden stroke.pdf?ua $=1$

WHO. (2021b). Disability-adjusted life years (DALYs). Retrieved from https://www.who.int/data/gho/ indicator-metadata-registry/imrdetails $/ 158$

Widjaja, K. K., Chulavatnatol, S., Suansanae, T., Wibowo, Y. I., Sani, A. F., Islamiyah, W. R., \& Nathisuwan, S. (2020). Knowledge of stroke and medication adherence among patients with recurrent stroke or transient ischemic attack in Indonesia: a multi-center, crosssectional study. International Journal of Clinical Pharmacy. doi:10.1007/s11096-020-01178-y

Zhao, J., Eckenhoff, M. F., Sun, W. Z., \& Liu, R. (2018). Stroke 112: A universal stroke awareness program to reduce language and response barriers. Stroke, 49(7), 1766-1769. doi:10.1161/strokeaha.118.021729

Zhao, J., Li, X., Liu, X., Xu, Y., Xu, J., Xu, A., . . . Liu, R. (2020). Changing the strategy and culture of stroke awareness education in China: implementing Stroke 1-20 . Stroke and Vascular Neurology, 5(4), 374-380. doi:10.1136/svn2019-000324 